\title{
BUSINESS ADMINISTRATION OPINION CONCERNING THE USE OF ACCOUNTING SOFTWARE IN ROMANIA
}

\author{
Assistant Ph.D. Student Horatiu Rotaru, rotaru horatiu@yahoo.com \\ The Romanian- American University, Bucharest
}

At the beginning of November 2006, the Internet web site www.conta.ro supported a competition with 41 participants where the users, after voting established the ranking of the top 10 accounting software. The most voted software was Ciel Contabilitate and Trendix. An interesting fact that Saga C and WizCount are not included in the top 10, this software being recommended by many users of the accounting group contabilitate@yahoogroups.com.

In this a work, the author has proposed to elaborate an empiric research concerning the accounting software, currently on the Romanian market, and drawing up an efficient and practical model, proposed for the use of the interested Romanian professionals in this field.

In the tax accounting field, that certain companies develop and the accounting department of companies with object of activity other than accounting, the software used by the firm is extremely important for obtaining performance and efficient results.

Every accounting software user asks himself: "What do I expect from the software I use?" and the answer I would suggest is: "I wish a software to which I tell: - Operate that folder of invoices, receipts, wages payroll and so on, this software executing the tasks without spending any time for registering every document, just to ask and the software to solve the problem. Unfortunately this represents the ideal solution for an accounting software that can not be applied currently, but who knows, maybe in a few years the accountants will be able to operate the documents through vocal commands.

In this work, the author has proposed to study some aspects of available software on the market, and also the results of this research to be available for use of the ones working in this field. In November 2007 the web site www.conta.ro (with the objective of debating the multiple problems and cases that appear in the activity of the accountants) along with „Curierul National”, „Prezent” and „Capital.Ro" (partner newspapers of the event) offered the chance for the users to vote their favorite accounting software for establishing a ranking, the object of the competition being "The best accounting software 2006", with the motto: "You have the software! The accountant has the remote control! Will he chose you?". At this competition 41 accounting software developers applied with software like: Vip Profesional, Datalight Enterprise, Wizpro, Winmentor, Easycont, Classoftsql Erp, Contab Sql, Syntesio, Claris, B-Org, Contabil Profesional, Aplix Erp, Trendix, Networker Erp, Ideale 2000, Pionier, Contab 04 Salevpers, Easycont, Ciel Finance Manager, Networker Erp, Trendix, Microinf and so on.

These software represent the majority of the Romanian market for accounting software, with advantages and disadvantages, the quality-price ratio being convenient or less convenient, friendly for the user or less friendly. Though the author wishes to mention that there is a possibility for some software to miss like Saga C, that should be integrated at accounting, remuneration section and so on.

Exhibit 1 reflects the result of the competition, this being the starting point for this work.

The first category is represented by ERP (Enterprise Resource Planning), as one can observe in the following table.

The first thing that must be established is what an ERP software represents. It is a system that integrates or tries to integrate more information and processes; a "key ingredient" is the use of a 
database with a single field witch gathers information belonging to different modules (such as accounting, remuneration, fixed assets, stock administration).

Exhibit 1

\begin{tabular}{|c|c|c|c|}
\hline Categoria & CASTIGATOR & LOCUL II & LOCUL III \\
\hline ERP & $\begin{array}{l}\text { COMETA } \\
\text { CONTAB SQL } \\
\text { COntabSQL } \\
\text { mm.cometa.ro }\end{array}$ & $\begin{array}{l}\text { BLUE LOGIC } \\
\text { TRENDIX } \\
\text { TRENDIX } \\
\text { Tmatrendix.ro }\end{array}$ & $\begin{array}{c}\text { CLASSOFT } \\
\text { CLASSOFTSQL ERP } \\
\text { CLASSOFFT } \\
\text { wnw.dassofit }\end{array}$ \\
\hline contabilitate & $\begin{array}{l}\text { CIEL ROMANIA } \\
\text { CIEL FINANCE } \\
\text { MANAGER } \\
\text { Mm.oiel.ro }\end{array}$ & $\begin{array}{l}\text { program retras } \\
\text { - premiul nu se acorda }\end{array}$ & $\begin{array}{l}\text { BLUE LOGIC } \\
\text { TRENDIX } \\
\text { TRENDIX } \\
\text { mam.trendix.ro }\end{array}$ \\
\hline Gestiune & $\begin{array}{l}\text { BLUE LOGIC } \\
\text { TRENDIX } \\
\text { TRENDIX } \\
\text { Trmatrendix.ro }\end{array}$ & $\begin{array}{l}\text { program retras } \\
\text { - premiul nu se acorda }\end{array}$ & $\begin{array}{l}\text { CIEL ROMANIA } \\
\text { CIEL FINANCE } \\
\text { MANAGER } \\
\text { mm.oiel.ro }\end{array}$ \\
\hline Salarii & $\begin{array}{l}\text { program retras } \\
\text { - premiul nu se acorda }\end{array}$ & $\begin{array}{l}\text { BLUE LOGIC } \\
\text { TRENDIX } \\
\text { TRENDDIX } \\
\text { Tmm.trendix.ro }\end{array}$ & $\begin{array}{l}\text { CIEL ROMANIA } \\
\text { CIEL FINANCE } \\
\text { MANAGER } \\
\text { mm.oiel.ro }\end{array}$ \\
\hline $\begin{array}{l}\text { Partida } \\
\text { Simpla }\end{array}$ & $\begin{array}{c}\text { AUTOSOFT } \\
\text { AUTOSOFT CONTPERS } \\
\text { mmm. autosoft.ro }\end{array}$ & 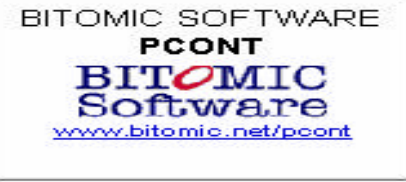 & - \\
\hline $\begin{array}{l}\text { Agentii de } \\
\text { turism }\end{array}$ & $\begin{array}{l}\text { MY SOFT } \\
\text { MYGEST TM } \\
M y \text { S of } t \\
\text { mm.mysoft.ro }\end{array}$ & - & - \\
\hline Imobilizari & $\begin{array}{l}\text { CIEL ROMANIA } \\
\text { CIEL FINANCE } \\
\text { MANAGER } \\
\text { mm.ciel.ro }\end{array}$ & 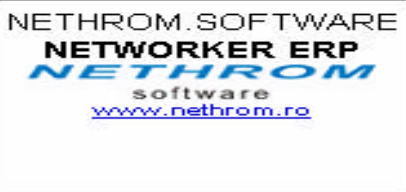 & 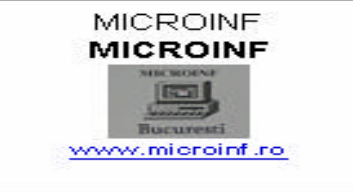 \\
\hline
\end{tabular}

The advantages of using an ERP software is that users don't buy many software for a certain segment which can not communicate directly. An frequent example is when the accounting is kept with a software and stock administration with another, the user being forced to operate the information from the stock software manually in the accounting software. This negative phenomenon which needs special attention and a long period of time is eliminated with ERP systems, the different segments mentioned earlier being integrated into a single software.

One of the disadvantages is the investments with training for this kind of software, and in some cases the lack of ways to protect the information inserted in the system. An example for this is the access of a person that operates invoices and also has access to other data, that don't concern them, like the remuneration of everybody hired in the company.

Another disadvantage is the high price for installation, the price of the annul license, the difficulty of changing the software with another because of the information and the processes contained by the ERP one wants to change, obstacles met when changing the interface, the necessity of collaborating, if not, hiring an programmer, and the most important, if a segment doesn't reach it's objective the others will be affected.

When analyzing ERP software, the first thing that must be established is the objective that one user buys them for. An example is represented by a firm that has employed only one person in comparison with one that has hundreds of employees, large stocks and fixed assets. Though for an 
firm that has the main objective of activity accounting and tax services, this might be the optimal solution, because of it's different clients.

Another element that must be taken in concern is financial accounting or accounting concerning stocks administration. For services object of activity the accounting can be kept as a financial accounting, while for an object of activity like production of good stock administration accounting is recommended.

The first place is occupied by "Contab SQL". The software has a friendly interface, easy to use although for the first time used. The main modules are: accounting, stock administration, fixed assets, wages and contracts.

The first disadvantage is the lack of economic and financial indices that allow management certain interpretation, the lack of functions that allow the user to observe what is the top of the clients, so certain reports necessary for an economist.

The second disadvantage is the heavily way to operate an invoice, many supplementary fields that should be used for a company with object of activity production of goods, so an option for this kind of problem would be helpful for a company that develops services.

Another omitted element is that in the accounting module this software can't determine automatically the VAT and elaborate de VAT form. The same omission applies to tax forms such as 100, 101 profit form, and also social contributions in the remuneration module and also for the balance sheet. This implies extra time spend by the accountant to compete manually these forms.

An negative argument is represented by the way the learning process develops, with very simple tutorials, without details, fact that disadvantages the system collaborated with the omission of a predefined company that should be installed in the same time with the software and should contain some accounting procedures as example.

The price for monopost version for a period of 12 months with updates and technical support is of $920 \mathrm{RON}+\mathrm{VAT}$, that equals 1094.8 RON.

The second place is occupied by "Trendix". The software contains the same modules as "Contab SQL". A favorable argument for this software is the interface, not as simple as "Contab SQL's", but what really matters is how fast and efficient one user can operate the economic transactions, costs of the software and updates, where it gains points.

An interesting aspect is the wizard the user can use when a similar transaction is operated and that operating the transactions can began by specifying the document to register.

At the disadvantages chapter the author must highlight the omission of the economic and financial indices, of an automated process that should elaborate the tax forms, of a preconfigured company used as an example for learning.

The price is of $285.6 \mathrm{RON}$ for a year periods with updates and technical support included.

The third place is represented by "VisualClassSoft ERP". The first impression when used is a good one because of the interface, but mostly because of the on-line tutorials. The remuneration module is competitive because it can elaborate automatically social contributions forms for remuneration module, presents the same characteristics as the competitors, though mentioning less printing options as "Trendix".

A negative element is represented by the accounting segment that doesn't completes automatically the tax forms and also the balance sheet. Other elements that influence the user's opinion are represented by the difficult way of creating an analytical account in the accounting module, being numbered from the number 1, creating difficulties for the user who operates transactions for multiple companies.

From the point of view of training, this software is situated before of it's competitors because of the video tutorials that allow an easy way of learning hoe to use the software.

The price is $1.600 \mathrm{RON}$ (VAT included) for a period of one year.

Exhibit 2 - VisualClassContERP, window used for registering invoices 


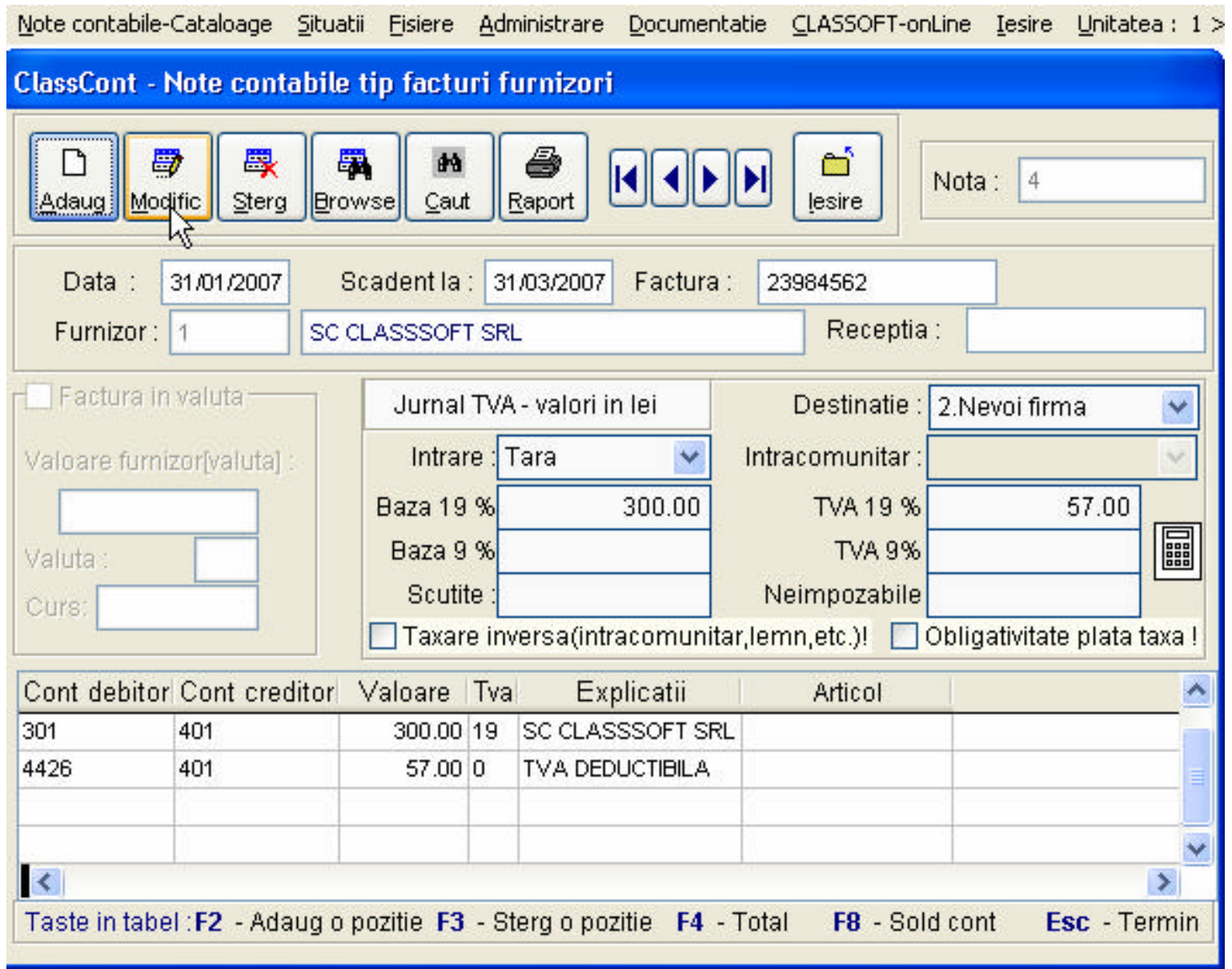

The conclusion for this section is that all ERP systems use modern technologies, such as connecting the server and the computers of the network through Internet and have online video tutorials, not just user's manual and Help section. An a general disadvantage for all the software presented earlier, the link between clients, suppliers invoices and the method of payment which is difficult.

An alternative for ERP systems is represented by the following software pachege: CIEL Finance Manager and Saga $\mathbf{C}$ with the same modules, but for CIEL the pachege is formed of 4 software: accounting and cash house, stock administration, remuneration, fixed assets, with the possibility of transferring the data between the 4 software mentioned earlier.

For accounting module, the first place is occupied by Ciel Contabilitate, followed by Trendix. Concerning Ciel Contabilitate it is known that it was the first software on the Romanian market, since 1991, so the team that develops Ciel has a great experience in this field. This can be observed, for example, by the way an invoice is operated, easily, even an inexperienced operator is able to register this kind of operations. The core of the software is structured as it follows: acquisitions journal, purchasing journal, cash house journal, bank journal and distinct operations journal (where assets depreciations, remuneration, costs and incomes are operated.

At acquisitions and purchasing chapter Ciel gains points, not like it's competitors, because of the rapid and effortless way invoices are operated, not like other software that don't allow creating an analytical account like 401.BT, for example, with letters in the symbol of the account in comparison with 401.01 that other software use, and it's hard to use because when one user has 100 suppliers and has to find the one representing 401.69, identifying the analytical account being hard to apply in other software. 
Exhibit 3 - Ciel Contabilitate, registering an invoice

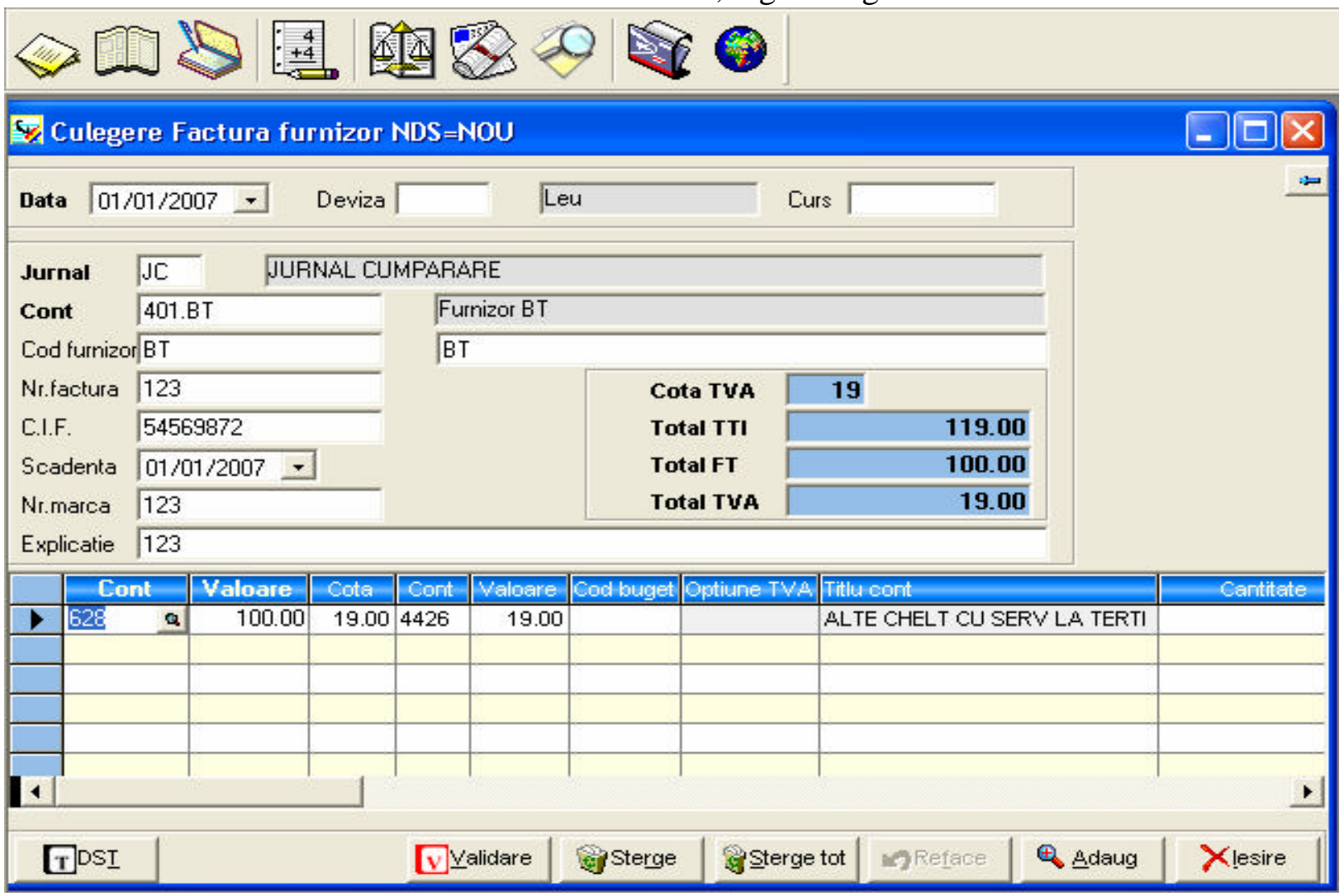

Annotation: The possibility of operating the analytical account401.BT, in other software it would be 401.05, for example

At distinct operation chapter Ciel has the advantage, not like the competition, to offer the possibility to generate models with a certain group of transactions, like wages/salaries or monthly depreciation of assets. In this way the structure of the recording is kept the same way, changing only the amount; this example is applied at remuneration, with the exception that when a change occurs all the amount must be changed. This model allows the accounting software user to work with other software also, for example salaries or fixed assets software.

At cash house chapter, the user has the possibility of printing the registry of cash house, option not possible at other software. Also concerning cash house and bank transactions the author wishes to highlight that these journals can be operated in a single window, making it more easier and faster to register transactions.

Concerning the reports and printing option, the user has the option of generating automatically the tax forms for VAT, profit tax and social contributions, this option being unavailable at other software.

Learning the software by the employees is facile because Ciel company supports it's users with online video tutorials, user's manual and help section with a preconfigured company as example for how to register transactions.

One major disadvantage at Ciel Contabilitate is that once the user has validated the transactions this operation is irreversible, option that Saga C makes possible. The reason the user wants to undo the validating is because he has found errors operated before validating the information. Another disadvantage is represented by it's price, around $600 \mathrm{RON}$, a bit pricy in comparison with others that offer more than just the accounting module.

Exhibit 4 - Saga S, operating a services acquisition invoice 


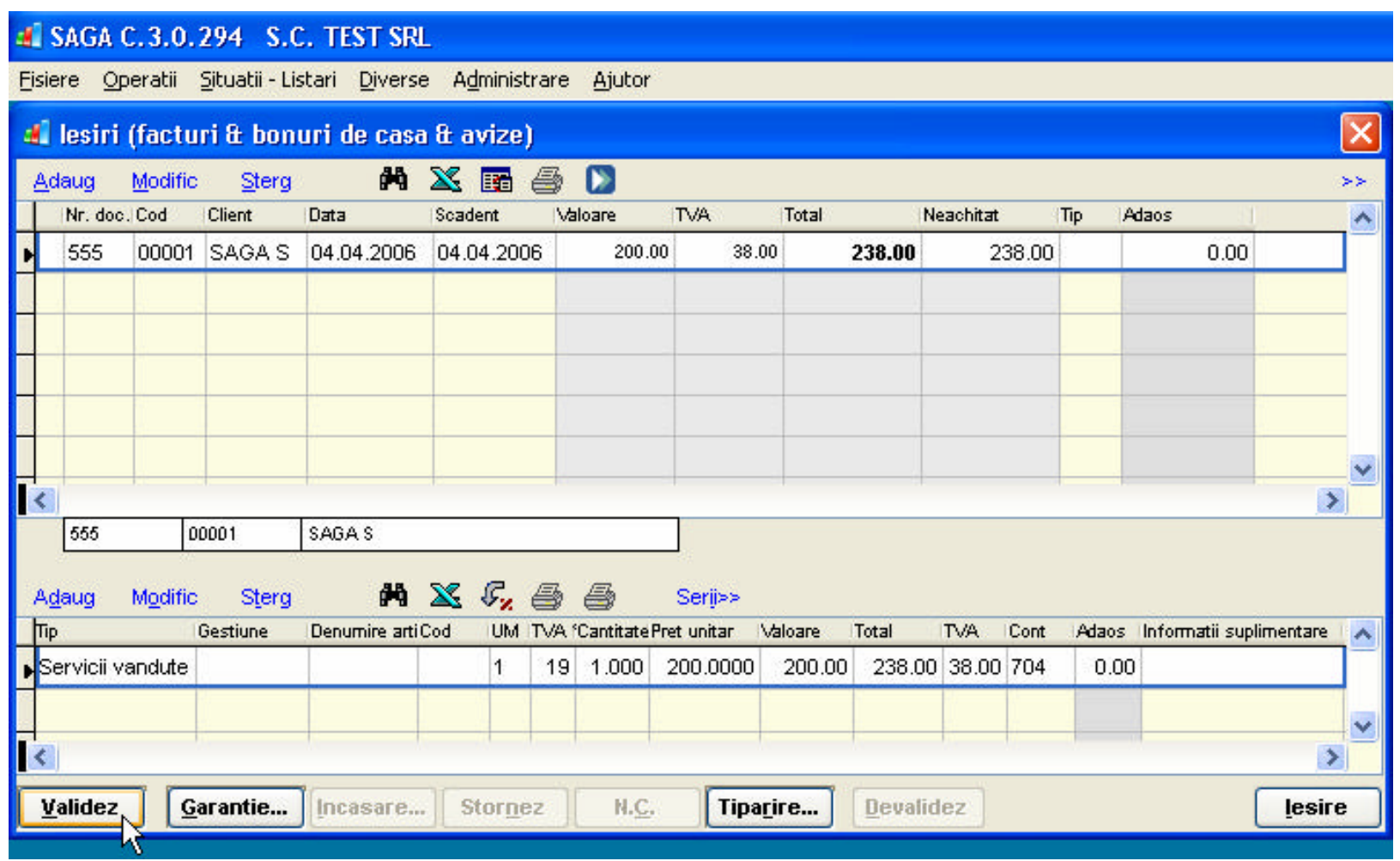

The conclusion for accounting module is that for a firm that develops tax, financial accounting activity for it's clients or for a firm that develops services, the recommended software to use would be Ciel Contabilitate, if the firm can afford this software. In comparison with other software it saves time and has an well organized core and it's easy to operate. For a small enterprise with a small amount of documents and few employees it's recommended to use Saga C, because of it's option to print tax forms and because of it's price.

The author proposes the implementation of tax and fiscal elements for accounting software, like the option of announcing the user if the turnover exceeded 35.000 Euro, limit for firms which are not registered as VAT payers, and the automated operation that modifies the fiscal vector and prints the necessary form, 010 . Also at this chapter of optimization the author proposes elaborating a fiscal calendar used inside the software that reminds the accountant of incoming dead-lines for tax forms, payments. None of the software described in this work have such an option.

At fixed assets chapter Ciel Imobilizari offers more functions that other software like accounts uses at immobilized accounts, Classifying catalog of fixed assets, printing the fixed asset form but doesn't allow the Depreciation Plan and Inventory Numbers Registry to be elaborated and printed. Though it realizes a more detailed evidence of fixed assets than it's competitors, but mentioning it's a pricy software reported to the competition.

Choosing an fixed assets software should be made reported with the needs of the accountant, but an evidence of the fixed assets can also be made using analytical accounts and the fixed assets form and depreciation plan can also be elaborated with Microsoft Excel. This solution should be used by a small size firm, with a restricted budget. For large companies with a great number of fixed assets and documents to register, concerning assets, the author recommends using Ciel Imobilizari, mostly because it allows the data to be transferred in Ciel Contabilitate. Ciel Imobilizari was voted as the most efficient software in this category.

At remuneration chapter the user must set as a primary objective the option of the software that allows the contribution forms to be completed automatically, including the Registry of employees evidence and employees fiscal forms. Ciel Salarii, Saga S and Trendix offer this possibility, but another factor influences this choice, the way the update are made by the developing company of the software, because there is a risk for the user not to be able to register a form due to 
a change of format for the form or the form generator software. The solution the author recommends for a small size company is Saga $\mathrm{C}$ because inserting the information referring to the remuneration is easy, using a single window, compared with Ciel Salarii, Trendix, VisualClasSal which need a lot of details. An special option is met at Ciel Salarii, a diskette is made for the bank to make the payments to the employees' personal bank account, representing the remuneration.

The last software that forms an accounting software package is represented by the commercial administration. The elements that such a software should meet are: connectivity to a cash register, possibility of transferring data through Internet, option of printing characteristic documents of stock class, operating the transactions should be made easy by a person with a medium level of IT knowledge.

An important aspect is represented by the data transfer to the accounting software. Thus, for accounting firms, the recommended solution is Ciel Gestiune Comerciala, because the stock and commercial administration is kept at the client's headquarters or another location, the information being easy to transfer to Ciel Contablitate. Another reason the author recommends using Ciel Gestiune Comercial is because of Ciel Conta Expert Contabil, which has the possibility of elaborating economic financial indices, inventory of assets, debts, cash-flow management and so on.

Another alternative is Trendix, more conveyable from the point of view of the price, but which doesn't assure connectivity with Ciel Contabilitate. Saga S is recommended to a society that hasn't got developed activity of stocks, operating payments and cash being more facile for an operator than other software.

\section{Bibliography:}

1. Keeping the Books: Basic Record Keeping and Accounting for the Successful Small Business, Linda Pinson, 2004

2. Ashutosh Deshmukh - Digital Accounting: The Effects of the Internet and ERP on Accounting, Idea Group Inc (IGI), 2006

3. http://accounting.comparison.softwareresearchtools.com/acct_compare/index.asp

4. http://www.conta.ro/programe_contabilitate.php

5. http://www.conta.ro/program/participanti.htm

6. http://www.conta.ro/program/vot.php

7. http://www.icomunicate.ro/comunicate-de-presa/comunicat/918/Vota355i-n-continuareTop-Programe-de-Contabilitate-2006

8. http://en.wikipedia.org/wiki/Comparison_of_accounting_software

9. http://www.smartfinancial.ro/smart/Afaceri+\&+Investitii/Conta.ro+va+realiza+Top+Pro grame+de+Contabilitate+2006

10. http://www.ciel.ro/

11. http://www.sagasoft.ro/

12. http://softmentor.ro/pagini/produse_marketmentorpro.aspx

13. http://www.fastcontab.ro

14. http://www.wizcontabil.com/index_ro.htm

15. www.cometa.ro. 